WIELKIE TEMATY KULTURY W LITERATURACH SKOWIAŃSKICH

Slavica Wratislaviensia CLXVIII • Wrocław 2019•AUWr No 3875

DOI: 10.19195/0137-1150.168.11

Data przesłania artykułu: 14.09 .2017

Data akceptacji artykułu: 8.02.2018

\title{
JAROSŁAW POLISZCZUK
}

Uniwersytet im. Adama Mickiewicza w Poznaniu, Polska

\section{Між карнавалом і смертю. Львівський досвід 1939-1941 років}

Проблема смерті, поширена на художню літературу, здатна викликати численні ідеологічні та значеннєві конотації. Досліджувати їі випадає принаймні у двох цілком відмінних напрямах, що означують так само феномен письма, як і його рецепцію в суспільній свідомості. Сама по собі художня творчість є мимовільним наближенням смерті або своєрідним програванням акту вмирання. Про це чимало написано в сучасній філософській думці, яка не випадково концентрувала увагу на аналогіях, що пов'язують літературу з рефлексією смерті. Так, Моріс Бланшо вказував, що вже сама функція описування світу веде за собою потребу зречення себе, а отже, ставить вимогу символічної смерті автора як творчої індивідуальності. Адже звернення до письма неодмінно корелює 3 пригніченням власної ідентичності, 3 необхідністю набувати інші тотожності, входити в істоту Іншого (що у принципі неможливо, якщо не поступатись власним „я”, і тут криється один із філософських парадоксів творчості). Бланшо твердив у цьому зв’язку, що „,исати себе - це перестати існувати", тобто передати свої повноваження комусь іншому, умовному читачеві й, отже, погодитись на те, що відтак твоє життя буде тривати „коштом твого неіснування”. Відтак, акт писання нерозривно пов’язаний зі смертю: „Коли я говорю, смерть говорить в мені”2 . Не ризикуємо тут доводити універсальність цієї тези, проте щодо багатьох літераторів та їхніх творів вона є досить-таки влучною формулою. Сам Бланшо розглядав у такому ракурсі твори Франца Кафки, але з не меншим успіхом можна поставити в подібний ряд також тексти Пауля Целяна, Чеслава Мілоша, Мi-

${ }^{1}$ Цит. за: М. Р. Markowski, Występek. Eseje o pisaniu i czytaniu, Warszawa 2001, c. 9.

${ }^{2}$ M. Blanchot, Literatura i prawo do śmierci, [в:] його ж, Wokót Kafki, пер. К. Kocjan, Warszawa 1996, c. 29. 
лорада Павича, Герти Мюллер чи Василя Стуса ${ }^{3}$. Чим більше письменник зрікається власного „я”, проектуючи на нього інші ідентичності й відчужуючи тим самим мовлення про самого себе, тим більше він підлягає цьому всеосяжному процесові культурної ентропії.

Інший вимір проблеми означує аналогія літературного побуту зі смертю. Побутова сторона літературного життя зазвичай опиняється на маргінесі дослідницького інтересу, оскільки їі трактують як зовнішній фон чи біографічний придаток до текстів, яким надаємо - 3 огляду на віру в естетичну самодостатність літератури - автономного статусу. Це поверхове і не вповні слушне уявлення. Щоб показати його поверховість, досить звернутися до конкретних артефактів літератури, які поставали в певних обставинах і великою мірою саме цим обставинам завдячують тими естетичними якостями, які в них поціновуємо. 3 іншого боку, відсутність оригінальних та переконливих художніх текстів у певні періоди - так само вимовне свідчення важливості літературного побуту. Маємо на увазі передусім драматичний досвід XX століття - війни, революції та повстання, депортації, наслідки тоталітарних режимів, зокрема в обмеженні громадянських прав, у цензурному тискові тощо. Усе це схиляє до думки, що ігнорувати суспільно-культурні чинники, утверджуючи самоцінність художнього тексту, недалекоглядно й немудро. А коли йдеться про період тоталітаризму, значення таких чинників для розвитку літератури слід визнати вирішальним. I це значення, варто підкреслити, проявляється не тільки в наявності певних знакових текстів доби, але й у їхній відсутності, у тих характерних культурних клаузулах, які виникають унаслідок витіснення 3 художнього дискурсу певних тем та мотивів, табуювання того, що владі видається небезпечним та недопустимим.

Середина двадцятого століття в Центрально-Східній Європі була позначена надзвичайним трагізмом, оскільки саме ці землі („,криваві землі”, за Тимоті Снайдером) опинилися в епіцентрі грандіозних та нечуваних за масштабом масових злочинів. Склалося на це багато причин. Проте сучасне звернення до пережитого в той час трагічного досвіду набуває актуальності ще й через те, що воно здатне оздоровити топографію колективної пам'яті, позбавити її іманентного трагізму та відчаю, притаманного наративові минулого:

[...] Легітимне порівняння мусить починатися з життя, а не зі смерті. Смерть не $\epsilon$ вирішенням, а лише суб'єктом. Вона мусить приносити неспокій, а не задоволення. Понад усе, вона не повинна бути завершальною риторичною фігурою, що приводить історію до визначеного кінця. Оскільки сенсу смерті надає життя, а не навпаки, то

${ }^{3}$ Ситуацію поміж філософією та літературою визнавав оптимальною для своєї творчості також Ж. Деррида, у текстах якого рефлексія смерті стала наріжним мотивом, що багато в чому визначив особливість його філософського мислення. Див. про це: J. Gutorow, Hotel Derrida, [в:] його ж, Życie w rozproszonym świecie: eseje, Wrocław 2016, c. 296-308. 
важливо спитати: Як можна було (як можна) привести таку велику кількість людських життів до наглого кінця? ${ }^{4}$.

Нижче буде запропоновано характеристику літературного побуту короткої історичної доби, яка, проте, стала знаковою в розвитку літератур східноєвропейського ареалу. Львів, вересень 1939-червень 1941 року. Неповні два роки. Час реалізації короткого, бо обірваного іншою, німецько-нацистською окупацією, радянського експерименту, внаслідок якого в рекордно короткий час місто, що було провідним культурним центром II Речі Посполитої, стало провінцією великого, але культурно поневоленого, зубоженого тоталітарною цензурою, Радянського Союзу. Час великих перетворень, великих обіцянок та надій, а також не менших розчарувань і страхів. Час, який назавжди (принаймні, на покоління вперед) змінив культурне обличчя Львова, але також усієї Галичини й Західної України, що була тоді приєднана до СРСР. I місце, яке досі має доволі контроверсійну історію, оскільки різні їі версії не тільки не збігаються в основі, а й лишаються відверто антагоністичними, навіть взаємно виключними. У цьому проблематичність Львова 3 його складною й суперечливою пам'яттю минулого, яку досі не можна розглядати безпристрасно. Адже йдеться про місто, „wobec którego nie wypracowano jednorodnych form pamięci zbiorowej, konglomerat fobii, resentymentów, traum i ran kilku narodów, wyznań i języków"5.

Говорячи про літературний побут у радянських умовах, слід виділити принаймні кілька маркерів, які будуть виражати його безумовну специфіку. У цій студії виділимо два аспекти, які, на наш погляд, дають можливість адекватно відчитати досвід радянського тоталітаризму в культурі. Це, по-перше, ритуальний характер організації літературного життя, і як наслідок, самої художньої творчості, що постає в цих умовах. По-друге, це поняття карнавалу, що передбачає подвійну або амбівалентну самоідентифікацію суб’єкта (передусім творця літератури, але також і їі споживача) в суспільстві неволі й регламентації. Ритуал виступає дієвим засобом успіху масової пропаганди, адже він привабливий, видовищний, повторюваний. Усе це сприяє тому, що через ритуал окремий індивід звільняється від потреби визначення власної позиції, власної оцінки дійсності, потрапляючи в наркотичну залежність від вибору, який накинутий згори, проте закріплений у зрозумілих та легких до засвоєння формах. У радянському суспільстві за час його існування було впроваджено низку ритуалів - революційних свят, календарних урочистостей, пов'язаних із культом праці, навіть родинних подій. Регулярна повторюваність забезпечувала ефективність дії

4 Т. Снайдер, Криваві землі. Свропа поміж Гітлером і Сталіним: монографія, пер. М. Климчука та П. Грицака, Київ 2011, с. 400.

5 A. Gajewska, Lemberg Land, Lwiw, Lwów. „Wysoki Zamek” Stanisława Lema jako opowieść uchodźcy, [в:] (P)O zaborach, (p)o wojnie, (p)o PRL. Polski dyskurs postzależnościowy dawniej i dziś, ред. H. Gosk, E. Kraskowskiej, Kraków 2013, c. 238-239. 
ритуалів на свідомість громадян. Основне завдання ритуалів - утвердження чинної системи влади, іï̈ ефективності та безальтернативності. Тому пріоритетними у масовій пропаганді виявляються „ритуали віталізації”, зміцнюють атмосферу довіри в суспільстві та всіляко легітимізують владу в очах громадян. Зворотну сторону репрезентують обмежувальні й репресивні рамки, що їх ритуал накладає на культуру, як слушно застерігав Мiхал Гловінський. Він зокрема писав:

Roczniceiświęta były elementem obrzędu, którego reguły obserwowano konsekwentnie, w sposób wykluczający jakąkolwiek swobodę, wszystko przeto, co wchodziło z nim w kontakt, miało być stosowne. A więc nie mogło wykraczać poza obowiązujące decorum, zharmonizowane $\mathrm{z}$ tym, co uznano za czynnik najważniejszy w danym przypadku. Rytuał ów wykluczał także $[\ldots]$ osobiste zaangażowanie poety $[\ldots]^{7}$.

Літературне життя (у цьому випадку доречно вживати термін тоталітарного літературознавства - літературний процес) в Радянському Союзі було цілком інтегроване в ритуальний колобіг. Адже в той період художня література, поряд із кінематографом та популярними жанрами музичних мистецтв, правила за найбільш ефективний інструмент масової пропаганди. Ïї не просто сприймають як носія ідеологічної доктрини режиму, ця доктрина має стати категоричним імперативом, витіснивши все, що не вміщається в формулу або може (навіть гіпотетично) їй суперечити. Через жорсткий контроль над творчістю, над організацією самого літературного життя комуністична влада домагається того, щоб насадити „єдино правильну” точку зору, аби письменники стали безкритичними пропагандистами офіційних ідей. Відбувається уніфікація художніх практик і суспільної рецепції самої літератури як галузі культурного виробництва. Тоталітарна влада цілеспрямовано зводила роль літератури до її обов’язку перед суспільством, акцентувала на соціальній місії красної словесності, а безпосередньою формою такого підпорядкування була теза про класовість літератури ${ }^{8}$. Очевидно, шляхи до такої уніфікації різні: хтось добровільно зрікається власних позицій, хтось стає запопадливим кон'юнктурником, хтось піддається пресові страху чи пасує перед загрозою репресій.

Оригінальну формулу тоталітарного суспільства запропонував свого часу видатний російський учений Михаїл Бахтін. Оскільки він працював в умовах цензурного тиску, та й сам зазнав репресій, то представив свою ідею як своєрідну алегорію. Маю на увазі відому бахтінську доктрину карнавалу, обгрунтовану в праці про Франсуа Рабле (1965) й безпосередньо пов'язану 3 європейським середньовіччям. Уважному читачеві М. Бахтіна зрозуміло, що його теорія має універсальний характер, а значить — може бути поши-

${ }^{6}$ В. В. Глебкин, Ритуал в советской культуре, Москва 1998, с. 74.

${ }^{7}$ M. Głowiński, Rytuał i demagogia. Trzynaście szkiców o sztuce zdegradowanej, Warszawa 1992, c. 105.

${ }^{8}$ В. В. Глебкин, Ритуал..., с. 57. 
рена й на інші формації. У наших умовах вона найкраще виражає власне сутність сталінської цивілізації несвободи. У бахтінській інтерпретації карнавалу варто виділити кілька важливих значень. По-перше, колективний характер цього явища, коли індивід відчуває себе ,членом масового народного тіла"9. Звідси - особливий спосіб сприйняття, характерний для учасників карнавалу. Зокрема, сприйняття часу: воно споріднене з архаїчним відчуттям нелінійності, циклічності часу ${ }^{10}$, коли те, що 3 нами відчувається, приречене на повторюваність. Смерть закономірно чергується 3 народженням, кінець із початком, тобто все повторюється. Така характеристика, як бачимо, зближує карнавал із ритуалом. Завважимо, що в сталінському суспільстві, де нормою були масові дійства (паради та демонстраціі) можливість вільного сміху лишалася цілком ілюзорною, на відміну від середньовічних спільнот, описаних М. Бахтіним. Цей сміх під тиском цензури перейшов у непублічну, вузько приватну сферу, а нерідко лишався не вербалізованим, у свідомості, щоб лишень по роках вийти наяву у спогадах або анекдотах. Бахтінська теорія карнавалу дає підстави для зрозуміння сутності й специфіки радянської ритуалістики, яка успішно використовувала досвід масових дійств, але також не менш успішно притлумлювала індивідуальну свідомість, мінімізуючи тим самим можливості спротиву тоталітарній владі.

Добрим прикладом ефективності ритуалу може слугувати організація літературного життя в Західній Україні в період 1939-1941 років, коли ця територія, згідно з угодою Молотова-Ріббентропа, була анексована Радянським Союзом. На цей час тоталітарна влада вже мала певні успіхи в підпорядкуванні літератури — від переломного Першого з’ізду та заснування на ньому Спілки письменників СРСР (1934) до кількох репресивних кампаній 30-х років. Інакше кажучи, система абсолютного контролю влади над літературою в країні вже була встановлена. Проте названий момент цікавий тим, як ця система впроваджувалась на відносно новому й непідготовленому терені, яким були західноукраїнські землі, і як їй вдалося відносно швидко та ефективно впоратися із „приборканням” незалежних письменників, зокрема через практики ритуальної „віталізації” культурного простору.

Можна виділити принаймні два етапи організації літературного життя в радянському Львові. Перший тривав приблизно рік: від вересня 1939-го року до вересня 1940-го року. Він забезпечив організаційне оформлення літератури, тобто створення Спілки радянських письменників у Львові, а також прийняття до цієї спілки місцевих авторів, що виглядало на своєрідну ініціацію. На другому етапі, що тривав неповний рік (жовтень 1940-червень 1941), вже було налагоджено видання журналів та газет, а також окремих колективних чи індивідуальних книжок львівських літераторів. Варто зазначити,

${ }^{9}$ М. Бахтин, Творчество Франсуа Рабле и народная культура Средневековья и Ренессанса, [в:] його ж, Собрание сочинений в 7-ми томах, т. 4, Москва 2010, с. 273.

10 Там само, с. 35. 
що якихось видатних творів у цей час не було написано, не в останню чергу через підневільне становище письменників і страх репресій, з одного боку, та ритуалізацію їхнього побуту, з іншого. Радянська модель літератури не стала продуктивною, незважаючи на формальну статистику, якою місцева номенклатура від літератури звітувала перед Москвою та Києвом.

Сьогодні непросто реконструювати літературну історію Львова 19391941 років. Адже чимало важливих деталей утрачено за давністю часу, а інші - були засекречені спеціальними службами. Неповними $є$ і спогади учасників тогочасного літературного життя, особливо ті, що написані в умовах радянської цензури, як-от Панча, Рудницького та ін. ${ }^{11}$, оскільки вони дають викривлений, ідеологічно закамуфльований образ подій. Найбільшу цінність мають спогади, що постали в позацензурних умовах, як-от Остапа Тарнавського ${ }^{12}$, Александра Вата ${ }^{13}$ тощо ${ }^{14}$. Додають істотні штрихи до характеристики того часу й наукові праці. Існує вартісна студія польського літературного життя та преси того періоду авторства Мєчислава Інгльота ${ }^{15}$, який скрупульозно зібрав також друковані та непубліковані тексти й різні супутні інформації, в тому числі від живих свідків історії; також інші корисні розвідки істориків ${ }^{16}$. Микола Ільницький дав досить зважену й докладну характеристику літературної ситуації 1939-1941 років у монографії Драма без катарсису (1999) ${ }^{17}$. Катажина Котиньська розглядає Львів у багатокультурному дискурсі, зіставляючи польські, українські та єврейські образи міста ${ }^{18}$. Згадані вище джерела дають змогу реконструювати характерні позиції різних письменників, а також поєднання індивідуальних авторитетів із колективними ритуалістичними практиками в осягненні поставленої владою мети.

11 Див.: П. Панч, Львів, Коперника, 42, „Вітчизна” 1960, № 2, с. 171-180; М. Рудницький, Письменники зблизька, кн. 3, Львів 1964.

12 О. Тарнавський, Літературний Львів, 1939-1944: спомини, Львів 1995. Пізніше також, з огляду на важливість для історії літератури, цю книжку було перекладено й видано польською мовою: О. Tarnawski, Literacki Lwów, 1939-1944. Wspomnienia ukraińskiego pisa$r z a$, пер. А. Chraniuk, ред. В. Bakuły, Poznań 2004.

${ }^{13}$ A. Wat, Mój wiek: pamiętnik mówiony, автор інтерв’ю і вступу C. Miłosz, Warszawa 1990.

14 J. Brzoza, Moje przygody literackie, Katowice 1967; Західна Україна під большевиками, Нью-Йорк 1958; H. Steinhaus, Wspomnienia i zapiski, опрац. A. Zgorzelka, Wrocław 2002.

15 M. Inglot, Polska kultura literacka Lwowa lat 1939-1941. Ze Lwowa i o Lwowie. Antologia, Wrocław 1995.

16 J. Chłosta, Polskie życie literackie we Lwowie w latach 1939-1941 w świetle oficjalnej prasy polskojęzycznej, Olsztyn 2000; Lwowskie życie pod okupacja sowiecka (1939-1941), ред. T. Bereza, Rzeszów 2006; Boy we Lwowie, 1939-1941. Antologia tekstów o pobycie Tadeusza Żeleńskiego (Boya) we Lwowie, опрац. В. Winklowa, Warszawa 1992.

${ }^{17}$ М. Ільницький, Драма без катарсису: Сторінки літературного життя Львова першої половини ХХ століття, Львів 1999.

18 K. Kotyńska, Lwów. O odczytywaniu miasta na nowo, Kraków 2015; Lwów: lustro. Obraz wzajemny mieszkańców Lwowa w narracjach XX-XXI wieku, ред. K. Kotyńska, Warszawa 2012. 
Досяжність швидкого результату в цьому випадку є феноменальною, адже владі вдалося здобути прихильну увагу більшості письменників, які не були прорадянськими i, більше того, в масі своїй мали опозиційні переконання. „Зліпити” таку спільноту можна було, звісно, шляхом умілого використання різних тактик - від загальних пропагандистських установок та радянських ритуалів, які слугували згуртуванню (чи то задля комуністичного майбутнього, чи то з перестороги щодо ворогів та їхньої загрози), до застосування індивідуального підходу - матеріальних заохочень, гонорарів, кар'єрного просування тощо. 3 іншого боку, не можна ігнорувати також репресивної практики, що була розгорнута з усією брутальністю та цинізмом у 1940-1941 роках. Проте, на відміну від легальної адаптації, яку влада активно рекламувала, каральна практика була старанно маскованою від громадської думки. Більше того, влада системно дбала про те, щоб громадську думку щодо цього заспокоїти та дезінформувати, а стан страху та оціпеніння, який переживали учасники літературного руху, мінімізувати. Так, резонансний арешт прокомуністичних польських письменників Вата, Броневського та ін. у січні 1940-го року був майстерною провокацією, внаслідок якої учасників конфлікту засуджено не за їхні політичні переконання, а за нібито хуліганські дії, що спричинило замішання та дезорієнтацію як у колі їхніх колег, так і серед ширшої громадської думки ${ }^{19}$. Авторитетні в Галичині Тарас Франко та Кирило Студинський безслідно „пропали”, їдучи у відрядження до Києва. А коли дружини репресованих осіб зверталися до очільника письменницької організації Петра Панча, той тільки розводив руками, зізнаючись, що не має жодного впливу на ситуацію ${ }^{20}$.

Складалося враження, ніби світла й темна сторона влади існують цілком автономно та не мають між собою зв'язку. Хоча об'єктивно радянська влада була зацікавлена у створенні монументального образу держави та одержавленої культури, проте іiї конкретні дії нерідко дискредитували цей образ. Для учасників літературного життя 1939-1941 років досвід радянізації був надто різким і гвалтовним. Якщо додати до цього непевну політичну ситуацію, внаслідок якої поділ Східної Свропи за угодою Молотова-Ріббентропа виглядав тимчасовим компромісом, стає зрозумілим занепокоєння і тривога, що неодмінно супроводжували львів'ян у повсякденному побуті. Обидва ці чинники - i об'єктивний стан речей, що вказував на крайню нестабільність поточного моменту, і діяльність нової влади - утверджували відчуття часу як тимчасового, перехідного стану. Це добре зафіксував у спогадах Петро Панч. Оцінюючи поведінку своїх підопічних письменників, що увійшли в новостворену організацію, він писав: „Вони все ще продовжували думати про радянську літературу і мистецтво, як про саму радянську владу, що це тільки експеримент, який невідомо ще чим закін-

${ }^{19}$ M. Inglot, Polska kultura literacka Lwowa..., c. 30.

${ }^{20}$ М. Ільницький, Драма без катарсису..., с. 49-50. 
читься"21. Заперечити це враження тимчасовості й заступити його відчуттям певності та стабільності - ось наріжне завдання більшовицької влади, яке здійснювали через упровадження радянської ритуалістики, через залучення письменників до спільної участі в ритуальних дійствах довкола освячених комуністичною пропагандою культів.

У літературній ситуації тогочасного Львова склався надзвичайний конгломерат сил: якщо до 1939 року в місті існували організації й товариства польських, українських та єврейських письменників і журналістів, то після приєднання до Радянського Союзу їхні стосунки було абсолютним чином переформатовані. Замість пріоритетних позицій польської літератури, що були безсумнівними в 20-30-і роки, влада поставила на українську, але в її радянському варіанті. Це означало, що українське письменство підлягало легітимізації настільки, наскільки відповідало офіційній формулі радянської культури, в якій посідало підпорядковану позицію. Принагідно наголошували на величі російської літератури, яка й була домінантою в Спілці письменників, цьому слугували також візити до Львова $з$ офіційною місією посланців Москви Алєксандра Фадєєва, Алєксєя Толстого та ін. Українські автори, які не декларували радянських поглядів або ще раніше засвідчили опозиційність щодо них, участь у національно-визвольному русі, як-от колишні молодомузівці (Петро Карманський, Василь Пачовський, Михайло Рудницький та ін.), підлягали досить-таки жорсткій люстрації, мали довести свою лояльність щодо комуністичного режиму. Тому-то декларації пріоритету української культури, яка відтак буде виведена зі стану дискримінації й посяде належну позицію, були принаймні нещирими, бо за ними приховувалась справжня політика, що схильна була маніпулювати українцями так само, як і іншими.

Інший пропагандистський слоган позиціонував СРСР як країну дружби народів та зразкового інтернаціоналізму. Однак і цей принцип у дійсності сповідуваний був вибірково, на догоду влади. За показною рівністю різних народів і культур нескладно було побачити, одначе, певну, офіційно утверджувану, ієрархію. По-перше, з кожної національної культури радянська ідеологія вибирала тільки ті постаті та факти, які ій пасували, а найголовніше - системно підпорядковувала їх своїм завданням. По-друге, декларована рівність виглядала на практиці надумано і штучно. Намагання поєднати те, що неможливо було поєднати на засадах раціональності, цілком відповідало бахтінській формулі карнавальної культури, в якій високе змішувалося 3 низьким і навпаки ${ }^{22}$. Не дивно, що така публічна риторика нерідко виглядала карикатурно. Проникливі спостережники завважили, що гасла інтернаціональної культури насправді виявляються демагогічними ${ }^{23}$,

${ }^{21}$ П. Панч, Львів, Коперника, 42, „Вітчизна” 1960, № 2, с. 179.

22 М. Бахтин, Творчество Франсуа Рабле..., с. 13.

23 Демагогічність - основа радянської пропаганди, як доводить М. Гловінський. Саме 3 цим фактором дослідник пов'язує успішність соцреалістичного мистецтва, що незважаю- 
адже за ними практично приховується домінування російської радянської культури, що iï слід було сприймати як безапеляційний зразок для наслідування. Таке враження відобразив відомий математик, професор Львівського університету Гуго Штайнгаус, який був уважним свідком і учасником радянізації Львова. Він зокрема писав про неспівмірність і нерідко просто-таки протиставність культів, об'єднаних у радянському каноні. I також, що прикметно, бачив за цим явищем глибшу підкладку, що зводилася до насаджування російської зверхності, нехай і прихованої гаслами рівності та взаємоповаги. Штайнгаус пише:

Kościuszko i Mickiewicz są uważani za swoich, ale Piotr Wielki i Suworow także. Gdy się pisze o Mickiewiczu, to należy zawsze wspominać Puszkina, a na dodatek różnych innych poetów tej klasy jak Łesia Ukrainka, albo współczesny poeta kazachski Dżambul. [...] Trzeba ich wszystkich w „Dżambul” chwalić, tak aby było jasne, że narodowość nie gra roli i że poeci tworzą zgrane towarzystwo, coś w rodzaju orkiestry grającej Międzynarodówkę do rosyjskiego tekstu ${ }^{24}$.

Отже, наявний статус українського письменника лише формально давав йому пріоритетну позицію, проте насправді очевидною була двозначність ситуації з проводом. У невизначеній, а нерідко й фрустраційній позиції опинилися польські письменники, для яких Львів був останнім бастіоном порятунку перед загрозою нацистської анексії Польщі. У вересні 1939 року польська інтелектуальна еліта змушена була тікати зі своїх звичних місць, і Львів став одним із центрів цієї вимушеної міграції. Загалом у місті тоді мешкало близько двохсот польських літераторів, причому значна частина ïx — ті, хто втікав у паніці вересня 1939 року з Варшави, Кракова, Лодзі та інших міст ${ }^{25}$. Вони ще не знали, яке випробування чекає в умовах радянського тоталітарного ладу. Їхні попередні біографії були пов’язані з творчістю в умовах відносної автономії культури: довоєнна Польща формально лишалася республікою, хоча в 30-і роки в їі правлінні також виразно позначились ознаки тоталітаризму. У подібному невизначеному статусі перебували i єврейські письменники. Вони прагнули зберегти своє право на розвиток культури власною мовою (їдиш), хоч би й за ціну лояльності до нової влади, яка виразно загравала з національними меншинами, пропагуючи політику інтернаціоналізму. До речі, 1939 року у Львові опинилась велика група євреїв із числа біженців, зокрема діячі культури - журналісти, музиканти, актори тощо.

чи на свою непослідовність, ба навіть абсурдність, мало певну популярність і сприймалося суспільством. Він зокрема пише: „Przyznać muszę, że socrealizm jako projekt propagandowy jest na swój sposób koncepcją genialną. Ale też skrajnie demagogiczną, bo świat zinterpretowany do najmniejszego szczegółu każe traktować jako odbicie tego, co istnieje, a sensy ideologiczne podsuwa czytelnikowi jako sprawozdania z rzeczywistości”. Див.: M. Głowiński, Rytuat i demagogia..., c. 16.

${ }^{24}$ H. Steinhaus, Wspomnienia i zapiski..., c. 213-214.

25 A. Wat, Mój wiek..., c. 303. 
Під час створення Спілки письменників було не тільки впроваджено єдиний, радянський стандарт літератури в іiї соцреалістичному й підцензурному вигляді, а й суттєво переформатовано впливи та домінанти. Якщо загалом у Львові тоді замешкувало близько 500 літераторів, то до новоствореної професійної спілки прийняли менше половини з них. Так, восени 1940го року організація письменників налічувала 162 особи ${ }^{26}$. Слід відзначити, що влада добре продумала поетапне включення творчих львів'ян у реалії радянської дійсності. Це зокрема проявилося в кадрових призначеннях. Під час першого візиту радянських письменників до Львова роль провідного спікера виконував Олександр Корнійчук, який поводив себе коректно і широко рекламував права та свободи в $\mathrm{CPCP}^{27}$. Далі були добре розписані ролі голів Спілки - Петра Панча та Олекси Десняка: обох призначено з Києва, узгоджено з Москвою, проте в поведінці вони були людяними й відносно доступними, на відміну від більшості радянських чиновників, які одразу ж набули авторитету хамських і брутальних щодо підлеглих, чим викликали осуд місцевого населення.

Одним із характерних професійних ритуалів став прийом до спілки письменників у вересні 1940 року. Він передбачав сувору співбесіду з комісією, під час якої кандидат мав довести свою лояльність щодо комуністичного режиму. Таку процедуру деякі письменники порівнювали 3 допитом $^{28}$. Вона фактично була різновидом популярного радянського ритуалу самокритики, суть якого зводилася до вишукування власних гріхів проти системи влади та щирого покаяння в цих гріхах. Одні ставились до цього ритуалу серйозно, інші сприймали його комічно, висміюючи сам ритуал у дружньому колі. Однак спільним для всіх було почуття страху, яке взагалі деморалізувало та зневолювало в тогочасних обставинах, коли методично працювала радянська каральна система, але також гостро відчувалося наближення великої війни, що на повну силу точилася в Свропі. Досить влучну характеристику ситуації дав М. Борвіч, що порівнював її з комедію dell'arte, в якій трагічні сцени розігрувались за кулісами, а найвеселіші репліки промовлялися втаємничено, поза офіціозом ${ }^{29}$.

У спогадах збереглися докладні описи прийому до спілки письменників, причому особливо цікаво спостерегти два його аспекти: 1. відверту театральність, що виражалась у відпрацьовуванні учасниками процесу певних, завчасу розписаних, ролей; 2. неймовірне психологічне напруження, яким цей акт супроводжувався. Такий ритуал назагал поєднує в собі раціоналістичний та ірреально-театральний складники, що й забезпечує йому силу впливу. Таким чином комуністичний ритуал самокритики „ujawnia

\footnotetext{
${ }^{26}$ М. Ільницький, Драма без катарсису..., с. 38.

27 Там само, с. 37, 39.

28 Там само, с. 28.

${ }^{29}$ M. Borwicz, Inżynierowie dusz, [в:] Boy we Lwowie..., c. 50.
} 
zakorzenienia marksizmu w oświeceniowej racjonalności z jednej strony i w typowo linearnej koncepcji sztuki — z drugiej"30.

Адаптація владою незалежних митців, упокорення та пристосування, зобов'язання до принизливої ролі служіння новому режимові приховує численні індивідуальні драми та трагедії. Часом це внутрішня криза й депресія, часом розрахунок (сподівалися, що комуністи ненадовго затримуються в Галичині), іноді фарс або легковажне загравання з монстром радянської пропаганди. Простіше з письменниками прокомустичної орієнтації, які щиро служили новій владі й сподівалися на неї, як-от Ярослав Галан, Степан Тудор, Владислав Бронєвський, Адам Важик, Ванда Васілєвська тощо. Складніше зрозуміти мотиви колишніх молодомузівців Михайла Рудницького, Петра Карманського, Василя Пачовського тощо. Або - молоду польськомовну поетку єврейського походження Зузанну Гінчанку, яка вже 1940 року написала й опублікувала кілька віршів та перекладів, створених цілком у дусі соцреалізму ${ }^{31}$ : щиро чи награно вона імітувала цей стиль, лишається загадкою. Або ж випадок видатного письменника й перекладача Тадеуша Боя-Желєнського, який розумів невідворотність процесу і наближення повної катастрофи, зокрема й власної смерті, а все ж зважився на інтригу з більшовицькою владою ${ }^{32}$. Спостерігаючи вчинки своїх колег, А. Ват доходив висновку про неможливість налагодити у тогочасному Львові нормальне спілкування, довірливі відносини через переслідування, доноси, інквізицію ${ }^{33}$. Навіть ті, хто мав незаплямовану репутацію та моральний авторитет у минулому, раптом зазнавали несподіваних і дуже прикрих метаморфоз.

Балансування поміж карнавалом і смертю, яке характеризувало ситуацію новонаверненого радянського письменника у Львові 1939-1941 років, відображає крихкість та вразливість літератури в умовах тоталітарного тиску. Письмо в таких обставинах утрачає свої найважливіші, найпитоміші ознаки. Ентропія досягає свого руйнівного впливу одночасно на кількох рівнях: 1. творчої особистості, що змушена зрікатися власної ідентичності; 2. товариського життя й обміну думками, що стає неможливим; 3. творення текстів, яке редукується через паралізуючий вплив цензури та самоцензури. Натомість на перший план виходить карнавально-ритуальна гра, що править за властивий сурогат повноцінного творчого життя.

${ }^{30}$ M. Shore, Kawior i popiót. Życie i śmierć pokolenia oczarowanych i rozczarowanych marksizmem, пер. M. Szuster, Warszawa 2008, c. 407.

${ }^{31}$ I. Kiec, Zuzanna Ginczanka. Życie i twórcość, Poznań 1994, c. 151.

32 A. Wat, Mój wiek..., c. 263.

33 Там само, с. 264-265. 


\section{Бібліографія}

Bakhtin M., Tvorchestvo Fransua Rable i narodnaya kul'tura Srednevekov'ya i Renessansa, [v:] yoho zh, Sobranie sochinenii v 7-mi tomakh, t. 4 (2), Moskva 2010.

Blanchot M., Literatura i prawo do śmierci, [v:] yoho zh, Wokół Kafki, per. K. Kocjan, Warszawa 1996.

Boy we Lwowie, 1939-1941. Antologia tekstów o pobycie Tadeusza Żeleńskiego (Boya) we Lwowie, oprac. B. Winklowa, Warszawa 1992.

Brzoza J., Moje przygody literackie, Katowice 1967.

Chłosta J., Polskie życie literackie we Lwowie w latach 1939-1941 w świetle oficjalnej prasy polskojęzycznej, Olsztyn 2000.

Fedoriv U., Demontuvaty ne mozhna zalyshyty: vypadok Stepana Tudora, „Ukrai'na Moderna”, http://uamoderna.com/demontazh-pamyati/fedoriv-stepan-tudor.

Gajewska A., Lemberg Land, Lwiw, Lwów. Wysoki Zamek Stanisława Lema jako opowieść uchodźcy, [v:] (P)O zaborach, (p)o wojnie, (p)o PRL. Polski dyskurs postzależnościowy dawniej i dziś, red. H. Gosk i E. Kraskowskiej, Kraków 2013.

Glebkin V. V., Ritual v sovetskoi kul'ture, Moskva 1998.

Głowiński M., Rytuat i demagogia. Trzynaście szkiców o sztuce zdegradowanej, Warszawa 1992. Gutorow J., Hotel Derrida, [v:] yoho zh, Życie w rozproszonym świecie: eseje, Wrocław 2016.

Il'nyc'kyj M., Drama bez katarsysu: Storinky literaturnogo zhyttja L'vova pershoi' polovyny XX stolittja, L'viv 1999.

Inglot M., Polska kultura literacka Lwowa lat 1939-1941. Ze Lwowa i o Lwowie. Antologia, Wrocław 1995.

Kiec I., Zuzanna Ginczanka. Życie i twórcość, Poznań 1994.

Klark K., Imperskoe vozvyshennoe v sovetskoi kul'ture 30-kh godov, per. N. Movninoi, „Novoe Literaturnoe Obozrenie" 95, 2009, http://magazines.russ.ru/nlo/2009/95/kk8.html.

Lwów: lustro. Obraz wzajemny mieszkańców Lwowa w narracjach XX-XXI wieku, red. K. Kotyńska, Warszawa 2012.

Kotyńska K., Lwów. O odczytywaniu miasta na nowo, Kraków 2015.

Lwowskie życie pod okupacja sowiecka (1939-1941), red. T. Bereza, Rzeszów 2006.

Markowski M. P., Występek. Eseje o pisaniu i czytaniu, Warszawa 2001.

Panch P., L'viv, Kopernyka, 42, „Vitchyzna” 1960, № 2.

Rudnyc'kyj M., Pys'mennyky zblyz'ka, kn. 3, L'viv 1964.

Shore M., Kawior i popiót. Życie i śmierć pokolenia oczarowanych i rozczarowanych marksizmem, per. M. Szuster, Warszawa 2008.

Snajder T., Kryvavi zemli. Jevropa pomizh Gitlerom i Stalinym: monografija, per. M. Klymchuka ta P. Grycaka, Kyi'v 2011.

Steinhaus H., Wspomnienia i zapiski, oprac. A. Zgorzelka, Wrocław 2002.

Tarnavs'kyj O., Literaturnyj L'viv, 1939-1944: spomyny, L'viv 1995.

Tarnawski O., Literacki Lwów, 1939-1944. Wspomnienia ukraińskiego pisarza, per. A. Chraniuk, red. B. Bakuły, Poznań 2004.

Wat A., Mój wiek: pamiętnik mówiony, avtor interv'ju i vstupu C. Miłosz, Warszawa 1990.

Zahidna Ukrai'na pid bol'shevykamy, N'ju-Jork 1958.

Slavica Wratislaviensia 168, 2019

(C) for this edition by CNS 


\section{Concerning carnival and death: Lviv between 1939 and 1941}

\section{Summary}

The author of this article focuses on the distinctive cultural situation in Lviv between 1939 and 1941. In October 1939, the process of merging of writers from three ethnic groups (Polish, Ukrainians and Jewish) into a single organization called The Union of Soviet Writers began. Such a situation can be interpreted with the help of Bakhtin's theory of carnival, especially while talking about the ambivalent behaviour of anti-communist writers. From another point of view, the main characteristics of the situation were fear, horror, and death threat, which each author experienced in his own way. The author of this article analyzes the memoirs of Ukrainian and Polish writers to portray this unexampled period and the repression of creative individuality by totalitarian authorities.

Keywords: carnival, literary life, ritual, totalitarian power, fear

\section{Между карнавалом и смертью. Львовский опыт 1939-1941 годов}

\section{Резюме}

В статье освещается исключительная культурная ситуация, сложившаяся во Львове в период 1939-1941 годов. В октябре 1939 года начинается процесс объединения писателей трёх группировок (польских, украинских и еврейских) в единую организацию - Союз советских писателей. Ситуацию того времени имеет смысл интерпретировать в свете категории бахтинского карнавала. С одной стороны, это касается амбивалентной позиции писателей-антикоммунистов. С другой стороны, ее характеризует состояния боязни, ужаса и угрозы гибели, которые каждый по-своему переживали участники литературной жизни. На основании воспоминаний польских и украинских писателей можем оценить беспрецедентность момента, а также прессинг тоталитарной системы на творческую индивидуальность писателя.

Ключевые слова: писатель, карнавал, ритуал, тоталитарная власть, страх

Slavica Wratislaviensia 168, 2019

(C) for this edition by CNS 